\title{
Interpreting Anselm's thought about divine justice: dealing with loose ends
}

\author{
Bernard J. D. van Vreeswijk \\ Grote Gracht 17, 8051 VH Hattem, The Netherlands \\ bjd@vanvreeswijk.nl
}

\begin{abstract}
Over the last fifty years studies of Anselm of Canterbury's concept of divine justice have delivered different results. The aim of this article is to present the results of a new comprehensive inquiry, based on the interpretation of key passages about justice in Anselm's theological works. The article argues that Anselm works with three definitions of God's justice. The first is the most traditional: God's justice is his right dealing with good and bad. The second definition follows the Anselmian concept of God: God's justice is his acting according to his being that than which nothing greater can be conceived. The third definition is God's rightness of will, preserved for its own sake. The article concludes that the attempt to show how these three definitions are related to each other brings to light tensions and loose ends in Anselm's works.
\end{abstract}

Keywords: Anselm of Canterbury, Cur Deus Homo, justice, mercy, Proslogion, De Veritate

Introduction

Anselm of Canterbury (1033-1109) has always been a landmark for theologians exploring the concept of justice. In this article I will attempt to analyse his ideas. In his Cur Deus Homo, which deals with the question why it was necessary that God became human, God's justice plays an important part. Divine justice was the reason why God had to become human and had to die for the sins of human beings. By sin humankind has offended God's honour, and God's justice demands satisfaction for this offence. In the past this thought has led theologians to sketch a grim picture of Anselm's God as severely and relentlessly demanding compensation because of his personally being offended. Although it is widely recognised that this picture was too grim, Anselm's views on God's justice and satisfaction continue to be approached with reservation. At the same time, however, it has been recognised, for example in a theological meeting between Pope Benedict XVI and scholars, that more research on Anselm's concept of satisfaction is 
needed. ${ }^{1}$ This article is intended as a contribution to that research by means of an exploration of Anselm's definition of God's justice. Research is needed because widely different definitions appear side by side in the literature. I will explain why this is the case and give what I believe to be an improved account of Anselm's thinking about justice.

An important contribution to a more nuanced view on Anselm's ideas about divine justice was made in 1973 by Gisbert Greshake. He published an article in which he gives a new interpretation of what Anselm meant by God's honour. ${ }^{2}$ According to Greshake the dishonouring of God was not a personal feeling of being offended. The honour of God was the righteous order of the world, by which the beauty of the creation and the wellbeing of creatures was upheld. Satisfaction is meant as restoration of this order. This speaking about God's honour is understandable from Anselm's sociological context. The honour of the king was the right-ordered society. Breaking this order was offending the honour of the king. Greshake gives some comments on the meaning of justice itself. ${ }^{3}$ He defines it as God's faithfulness to himself and to humankind. He takes his arguments from Cur Deus Homo, but he does not show that in this book Anselm himself uses iustitia in this sense. Neither does he show how this sense of justice is related to other parts of Anselm's works. So we need to look at other interpretations as well. I start with interpretations from two authors, each of whom aims to give a survey of Anselm's thinking about God's justice. ${ }^{4}$

The first is the interpretation of Alister McGrath in his handbook Iustitia Dei: A History of the Christian Doctrine of Justification. He gives two interpretations of justice side by side. First, God's justice as his action directed towards the highest good that may lead to human redemption; in the second place,

1 Peter Kuhn (ed.), Gespräch über Jesus. Papst Benedikt XVI. im Dialog mit Martin Hengel, Peter Stuhlmacher und seinen Schülern in Castelgandolfo 2008 (Tübingen: Mohr Siebeck, 2010), pp. 95-104.

${ }^{2}$ Gisbert Greshake, 'Erlösung und Freiheit: Zur Neuinterpretation der Erlösungslehre Anselms von Canterbury', Theologische Quartalschrift 153 (1973), pp. 323-45. Earlier Eugene Fairweather pointed out that the right ordering of things belonged to the kernel of God's justice: “'Iustitia Dei” as the Ratio of the Incarnation', in Spicilegium Beccense 1. Congrès International du IX Centenaire de l'Arrivée d'Anselme au Bec (Paris: Librairie Philosophique J. Vrin, 1959), pp. 327-35. Another milestone in the development to an improved account of Anselm's concept of justice is Robert Pouchet, La Rectitudo chez Saint Anselme: Un itinéraire augustienne de l'âme à Dieu (Paris: Etudes Augustiennes, 1964). He stresses the meaning of justice for Anselm as the rightness of will; so, too, does Thomas F. Torrance, 'The Ethical Implications of Anselm's De Veritate', Theologische Zeitschrift 24 (1968), pp. 309-19.

3 Greshake, 'Erlösung und Freiheit', 338.

${ }^{4}$ Other and less comprehensive studies I have left aside in the main text, for reasons of clarity. I will discuss them in the footnotes. 
justice is understood as rectitude of will preserved for its own sake. McGrath takes the first definition from Anselm's Proslogion and the second from De Veritate. Besides these two definitions, McGrath states that God's character as supreme justice is expressed in the moral order of creation, and that the moral order cannot be violated because God's nature as supreme justice then would be violated. McGrath does not, however, say in so many words that God's justice means his upholding of the moral order. Moreover, he contends that according to Anselm God's justice leads to human salvation because it is not just for God to fail in his intention with mankind. ${ }^{5}$ McGrath does not explicate how the two definitions are related to each other. ${ }^{6}$ Like Greshake, he doesn't show that in Cur Deus Homo iustitia means that it is not just for God to fail in his intentions ${ }^{7}$

The other interpretation to be mentioned is that of Michel Corbin, the French translator and editor of the works of Anselm. As I understand Corbin, his interpretation is as follows. Anselm works with a twofold divine justice. First, God is just because for Him it is just that mercy exceeds justice. ${ }^{8}$ This implies for Corbin the meaning of justice as God's surpassing every conceivable justice. ${ }^{9}$ Second, God's justice is his rewarding good and bad. ${ }^{10}$ According to Corbin, God's justice as surpassing every justice prevails and

${ }^{5}$ Marilyn McCord Adams contends the same in her 'St Anselm on the Goodness of God' in Giles E. M. Gasper and Ian Logan (eds), Saint Anselm of Canterbury and his Legacy (Durham/Toronto: Pontifical Institute of Mediaeval Studies, 2012), p. 367. Likewise Georg Plasger, Die Not-Wendigkeit der Gerechtigkeit: Eine Interpretation zu 'Cur Deus Homo' von Anselm von Canterbury (Münster: Aschendorff Verlag, 1993), pp. 167-9. He explains God's justice as his covenantal faithfulness. God's justice is his will to lead man to salvation.

${ }^{6}$ Like McGrath, McCord Adams points to the two kinds of justice without explaining how they are related (McCord Adams, 'St Anselm on the Goodness of God', pp. 365-74).

7 Alister E. McGrath, Iustitia Dei: A History of the Christian Doctrine of Justification (Cambridge: CUP, 2005), pp. 75-81.

8 Anselm of Canterbury, Lettre sur l'incarnation du Verbe, Pourquoi un Dieu-Homme, ed. and trans. Michel Corbin and Alain Galonnier (Paris: Éditions du Cerf, 1988), p. 46.

${ }^{9}$ Ibid. Cf. Michel Corbin, La Pâque de Dieu. Quatre études sur S. Anselme de Cantorbéry (Paris: Éditions du Cerf, 1997), p. 58; idem, Espérer pour tous: Études sur saint Anselme de Cantorbéry (Paris: Éditions du Cerf, 2006), p. 204. Klaus Kienzler thinks along the same lines in his Gott ist grosser: Studien zu Anselm von Canterbury (Würzburg: Echter, 1997), pp. 153-61. In Gerhard Gäde, Eine andere Barmherzigkeit: Zum Verständnis der Erlösungslehre Anselms von Canterbury (Würzburg: Echter, 1989), esp. pp. 274-85, the author shows the importance of God as that than which nothing greater can be thought for Anselm's thinking about mercy and justice in Cur Deus Homo. He contends that God's justice and mercy are transcending human categories, and that it is Anselm's aim to quarantine God's absoluteness.

10 Corbin, Espérer pour tous, p. 204. 
leads to God not punishing the sinner. ${ }^{11}$ In the next paragraphs I will explore the question whether these interpretations are right. In order to do so I will look at the three works of Anselm which give thorough insight on his concept of justice. These works are Proslogion, De Veritate and Cur Deus Homo. ${ }^{12}$

\section{Proslogion}

In Proslogion, IX-XI Anselm deals with the problem how God can be righteous when he spares a wicked person, because God's justice means that he rewards people according to their doing right or wrong. So when Anselm starts thinking from the aspect of God's justice, he does not understand why God can spare the wicked. But when he approaches this question from the aspect of God's goodness, he can see why God spares the wicked. The reason lies in the nature of God. Anselm describes God as that than which nothing greater can be conceived. Because God's nature is such, he will be better when he is not only good for the good people, but also for the wicked people. In this way of reasoning we recognise Anselm's important definition of God as the being nothing greater than which can be conceived, as he formulates it when he argues for God's existence. ${ }^{13}$

But how does this goodness then relate to divine justice? How can it be just to reward the wicked with good? That is a big question for Anselm. Because for him God's goodness must relate to God's justice, since goodness is never apart from justice, and what is more, God's goodness derives from his justice. Therefore he supposes: 'Is it because it is just that You are so good that You cannot be conceived to be better, and that You act with so much power that You cannot be thought to be more powerful? For what is more just than this?'14

So he seems, be it tentatively, to give a new meaning to justice to solve his problem. God is just in that he is and acts in such a manner that he cannot be

11 Ibid., p. 220. Paul Gilbert, 'Justice et miséricorde dans le Proslogion de Saint Anselme', Nouvelle Revue Theologique 108 (1986), pp. 218-38, and “Le "Proslogion" de St. Anselme: Silence de Dieu et joie de l'homme (Rome: Editrice Pontifica Università Gregorian, 1990), pp. 12440 , can be seen as working with a comparable twofold definition of God's justice, although he elaborates it in a different way.

12 Anselm of Canterbury, Proslogion, in Opera Omnia, ed. Fransiscus S. Schmitt (Edinburgh: Apud Thomam Nelson et Filios, 1946-61), vol. 1, pp. 89-122; De Veritate, in Opera Omnia, vol. 1, pp. 169-200; Cur Deus Homo, in Opera Omnia, vol. 2, pp. 37-134. The Roman numerals in the citations below refer to the chapters of the works of Anselm; the Arabic numerals refer to the page numbers and line numbers in the edition of Schmitt.

13 Anselm, Proslogion, II.101.4-5.

14 Anselm Proslogion, IX.108.11-13. Translation from Anselm of Canterbury, The Major Works, ed. Brian Davies and Gillian R. Evans (Oxford: OUP, 1998), pp. 92-3. 
conceived to be greater. Therefore it is just that he is so good that he cannot be conceived better. God is better when he is not only good for the good but for the wicked too. From this point of view on justice, Anselm can relate God's goodness to God's justice and show why it is just that God spares the wicked.

After this conclusion, however, he does not reject the former definition of justice, i.e. God's rewarding according to good or bad. Therefore he can still say: it is more just (in the sense of rewarding according to good or bad) not only to reward the good, but also the wicked. Rewarding only one type of people is less just in Anselm's eyes. Now Anselm confronts a new problem. How can it be the case that both saving the wicked and punishing the wicked are just, depending on which definition of justice he uses? He tries to solve this problem by a twofold distinction of justice, namely between justice according to us (iustitia secundum nos) and justice with respect to God (iustitia secundum te). ${ }^{15} \mathrm{He}$ is not very clear as to what he means by this distinction. Moreover, it does not seem very satisfying to Anselm himself, because for him punishing the wicked is not only just with respect to us, but also with respect to God himself. Because the justice of God himself will be greater when he not only bestows the good on the wicked, but when he rewards the wicked with evil, too. So, thinking from God's character a strange possibility arises: following his justice, God can spare and punish the sinner. God spares one sinner and punishes the other, depending on his will. And what God wills is always just. ${ }^{16}$ But now he has created a new problem, a problem which we do not discuss in this article and which so far as I can see, Anselm does not explicitly address. Why God should wish to punish one sinner and to save the other, Anselm cannot grasp. But both punishing and saving are just. $^{17}$

So we see that Anselm works with two meanings of justice in Proslogion. Justice in the sense of God acting as befits his being that than which nothing greater can be thought, and justice as rewarding good with good and bad with bad. The tension that this twofold definition produces, when God exercises the one justice and when the other, Anselm dissolves only partly by having recourse to God's will, which is always just. ${ }^{18}$

15 Anselm, Proslogion, IX.108.21-109.6.

16 Anselm, Proslogion, IX.109.8-20.

17 Anselm, Proslogion, IX.109.21-4.

${ }^{18}$ See also Gregory B. Sadler, 'Mercy and Justice in St. Anselm's Proslogion', American Catholic Philosophical Quarterly 80 (2006), pp. 41-61. Sadler argues, rightly in my opinion, that Anselm's discussion of the relation of mercy and justice is an exploration of God's nature as that than which nothing greater can be thought. He also signals the tension 
In Proslogion, IX-XI Anselm does not make clear why it is just that God acts according to his being that than which nothing greater can be conceived. He only puts forward the question: is it just because you are and act so as you cannot be conceived greater? He answers this question in the affirmative. We will look further to see if we can get a clearer understanding of why it is just for Anselm that God is and acts in this way. To this end we will analyse a passage of De Veritate.

\section{De Veritate}

In De Veritate Anselm deals with human justice. In De Veritate, XII Anselm looks for a definition of justice. But after his inquiry into the definition of human justice, he remarks in this chapter that this definition applies to no one better than to God. So we will explore now his definition of justice. He defines 'justice' as 'rectitude of will preserved for its own sake'. ${ }^{19}$ For Anselm you are just when you will what you ought. But that is not enough, the reason why you want the right things is very important. When you do the right things, because you do not like to be punished, you are not yet just. Only when you do the right things, because you want to do so because of their rightness, are you just. Although this definition applies to man as well as to God, what 'rectitude of will' means for God or man differs. For man 'rectitude of will' is 'being subjected to the will of God'. But God cannot be subjected to himself. What does it mean for God then?

We look for an answer to this question in Anselm's explanation why the definition of justice is most fitted for God.

Licet non ibi sit aliud voluntas, aliud rectitudo, tamen sicut dicimus potestatem divinitatis aut divinam potestatem sive potentem divinitatem, cum in divinitate non sit aliud potestas quam divinitas: ita non inconvenienter dicimus ibi rectitudinem voluntatis aut voluntariam rectitudinem seu rectam voluntatem. Si vero illam rectitudinem dicimus propter se servari, de nulla alia rectitudine sic convenienter dici posse videtur. Sicut enim non aliud illam sed ipsa se servat, nec per aliud per se: ita non propter aliud quam propter se. ${ }^{20}$

in God's justice. He is not explicitly searching for a definition of God's justice and does not take Anselm's other works into account.

19 Anselm, De Veritate XII. 194.26.

${ }^{20}$ Anselm, De Veritate XII.196.1-8. See for an explanation Markus Enders, Wahrheit und Notwendigkeit. Die Theorie der Wahrheit bei Anselm von Canterbury im Gesamtzusammenhang seines Denkens und unter besonderer Berücksichtigung seiner Antiken Quellen (Aristoteles, Cicero, Augustinus, Boethius) (Leiden: Brill, 1999), pp. 528-9. 
The background of this remark is the doctrine of simplicity: there are no parts in God; he is identical with his attributes. ${ }^{21}$ So God's being is identical with his justice. When God preserves his justice, he preserves himself. And when Anselm says, 'Si vero illam rectitudinem dicimus propter se servari, de nulla alia rectitudine sic convenienter dici posse videtur', we interpret that it cannot be said more properly, because he is most of all in himself worthy to be preserved. Preserving himself means preserving himself as the being greater than which nothing can be conceived, although Anselm does not explicitly say this. ${ }^{22}$

So we may conclude: when God preserves justice, he preserves himself. By extrapolating Anselm's thought, preserving himself means that he preserves himself as the being greater than which nothing can be thought. His justice means therefore that in everything he does, he preserves himself as the being greater than which nothing can be thought. He is just in that he is so wise that he cannot be thought wiser. He is just in that he is so good that nothing better can be thought. He is just in that he is so powerful that more powerful cannot be thought. In the same way, he is so just that he cannot be thought more just (in the sense of rewarding good with good and bad with bad). The tension in Proslogion appears again here and finds its roots in the definition of God's justice as maintaining himself as the being than which nothing greater can be conceived. He is just in punishing and just in saving.

${ }^{21}$ See Enders, Wahrheit und Notwendigkeit, pp. 526-8; Anselm, Über die Wahrheit, ed. and trans. Martin Enders (Hamburg: Meiner, 2001), CIII; Heinz Külling, Wahrheit als Richtigkeit: Eine Untersuchung zur Schrift 'De veritate' von Anselm von Canterbury (Bern: Peter Lang, 1984), pp. 252-3. See also Ubaldo R. Pérez-Paoli, 'Truth and Justice in Anselm of Canterbury', Graduate Faculty Philosophy Journal 17 (1994), pp. 127-51, esp. 140; and Brian Leftow, 'Anselm's Perfect-Being Theology', in Brian Davies and Brian Leftow (eds), The Cambridge Companion to Anselm (Cambridge: CUP, 2004), pp. 132-56.

22 Here I differ from Enders. According to him, propter se means that God is the ground for his own being (Enders, Wahrheit und Notwendigkeit, p. 528; so too, Külling, Wahrheit als Richtigkeit, pp. 253-4). It can be argued, however, that as propter se refers to the worth of justice in itself as the reason why it has to be preserved, propter se with respect to God refers to his worth that has to be preserved more than anything else. Further, Enders leaves unanswered in his discussion of De Veritate, XII what this preserving means. Earlier in his study dealing with De Veritate, he explains what Anselm means by rectitude with respect to God. Anselm says that God owes nothing to anyone else. In Enders' interpretation this means that God must act according to his own nature as the being than which nothing greater can be thought. He then refers to Anselm's later book Cur Deus Homo (cf. Anselm, Über die Wahrheit, LXXIX). In the next paragraph I will analyse Cur Deus Homo, and then I will return to Enders' interpretation. 


\section{Cur Deus Homo}

Until now we have seen that Anselm uses the justice of God in two ways. In one sense, he speaks about God's justice with regard to his dealing with morally good and bad ways of acting. In the other sense, he speaks about God's justice as his being and acting according to his own being, further explicated as acting according to his being that than which nothing greater can be conceived (as in Proslogion) or as preserving himself (as in De Veritate). These two ways of speaking about God's justice are not contradictory, of course, but they give rise to tension, as we have seen in Proslogion.

When exploring Cur Deus Homo, it is remarkable that in this book Anselm does not give a definition of justice, although the first sense is prominent. ${ }^{23}$ It seems to me a challenge to read Cur Deus Homo also from the perspective of the second sense. It is an open question why Anselm in Cur Deus Homo does not stretch his line of thought from Proslogion to De Veritate, where he seems to interpret God's justice more and more as God's willing what is fitting for him as the being than which nothing greater can be thought. In Cur Deus Homo he seems to go back to the beginning of his thinking about justice in Proslogion, IX, where he defines justice as God's just dealing with right and wrong. One reason for the choice of this definition could be Anselm's policy of reasoning. He wants to start on common ground with unbelievers. For unbelievers the meaning of justice would only have been dealing with good and bad. Another explanation could be that Anselm had not finished his work on Cur Deus Homo when (as he writes in the preface) other people published it without his knowledge. ${ }^{24}$ But because Anselm speaks there about 'insertions' and 'additions', he probably does not refer to his thinking about the definition of justice, which is more than something still to be inserted or added. A third reason is the path Anselm takes to get insight. 'Anselm exacerbates problems into contradictions and then, in astonishing reversals, transforms those paradoxes into claims that are not only true but necessarily true', according to Eileen Sweeney. ${ }^{25}$ In Cur Deus Homo he works perhaps with that meaning of God's justice that creates tension and not with that aspect that loosens the tension in advance.

First let us explore a little further the role and meaning of divine justice in the first sense in Cur Deus Homo. In this way we will get a clearer picture

23 See e.g. Anselm, Cur Deus Homo, I.VIII.60.1-10, I.XII.70.11-30, I.XXIII.90.28-91.29, I.XXIV.92.1-94.22, II.II-III.98.6-98.26. In Proslogion Anselm seems to use 'just' in the first sense of justice as rewarding good and bad; in Cur Deus Homo he seems to use it in the somehow broader sense of 'legitimate' or 'justified'.

${ }^{24}$ Cur Deus Homo, Praefatio, 42.1-6.

25 Eileen C. Sweeney, Anselm of Canterbury and the Desire for the Word (Washington, DC: Catholic University of America Press, 2012), 9. 
of God's justice from Anselm's point of view. When we look at the flow of argument, the following type of reasoning arises: 'If we can determine what is just, then we can suppose that God will do this.' Of course, the idea behind this reasoning is his project to draw a conclusion by reason alone. But there is a theological reason besides that: although God's ways may not always be comprehensible to us, he will never act in an irrational way. ${ }^{26}$ It is noteworthy that Anselm in Cur Deus Homo nowhere links God's justice inherently to a certain kind of law or procedure of sanctioning and that he seldom uses the term lex (law). When he deals with the notion of satisfaction he does not say, 'These are the rules and they cannot be broken, not even by God. There is nothing we can do about it.' Nor does he say, 'This is the way God wills it, you have to accept it.' Instead, he searches for what is the right way of dealing with doing wrong to someone and then concludes: if that is the right way, then God will do that. ${ }^{27}$ To show this we can look at an example he uses to explain the role of satisfaction. This example makes clear how Anselm is reasoning. He looks at the reality of everyday life and asks himself: how does it work? What is right? The example he uses is the situation in which someone has harmed somebody else's health. What is right in that situation will be right in the relation between God and human beings. When it is right to give satisfaction to the person who has been harmed, it is right for the sinner to give satisfaction to God. ${ }^{28}$ The expression 'it is just' must therefore not be understood too much in a juridical sense, but more in the sense 'it is right', and that is something you can argue about. It is illuminating to see how Anselm can join the words 'just' and 'reasonable' as more or less alternatives. ${ }^{29}$ What is fundamentally right is never arbitrary for Anselm, but always rational. That does not mean, however, that we always have insight in the reasons God has for acting. His reasons can be hidden. ${ }^{30}$ So when we attempt to evaluate Anselm's doctrine of satisfaction and to do justice to his project, the question should not be which image of God he has, but rather, how must we evaluate Anselm's view on what is (rationally) the right way to restore a relation, such that, once the answer to that question has been determined, it is reasonable to believe that God will act in this way too?

Now we will look at justice in the second sense in Cur Deus Homo. As we have just mentioned, it seems that in this book Anselm does not explicitly use the second sense of God's justice, as willing what is fitting for him or

26 Anselm, Cur Deus Homo, I.VIII.59.10-11.

27 Ibid., I.XI.67.1-6.

28 Ibid., I.XI.68.14-69.2.

${ }^{29}$ Ibid., I.VIII.60.2-5.

30 Ibid., I.II.50.1-13. 
as preserving himself. This does not mean that he does not use phrases like 'it is fitting for God'. He does. And what is more, the question of whether something is fitting for God is crucial in his discourse. ${ }^{31}$ It plays a role from the very start of book II, in which he writes how God will give a solution for the problem of book I, that human beings have to give satisfaction but have no possibility of doing so. ${ }^{32}$ By arguing what is fitting for God, he demonstrates in book II the necessity of the incarnation. Three things, however, he does not do. To begin with, he makes no relation with God's justice as his doing what is fitting for him. ${ }^{33}$ Furthermore, he does not link what is fitting for God to his being that than which nothing greater can be thought, as he does in Proslogion. ${ }^{34} \mathrm{He}$ only says that in God something unfitting results in an impossibility, and that the rational best choice leads to necessity. ${ }^{35}$ Finally, nowhere in Cur Deus Homo does he bring together God's inability to do something that is not in accordance with his nature with his preserving his own being as in De Veritate, ${ }^{36}$ although it is near to his mind, as we shall now see.

We will look at three passages of Cur Deus Homo, where Anselm comes close to the idea of God's justice as willing or doing as is fitting for him as the being better than which nothing can be thought.

The first passage is Cur Deus Homo, I.XII. In this passage Anselm is arguing about the question of whether something is right because God wills it, and, therefore, if lying can be right, because God wills it. Anselm confirms that, when God wills something, it is just, but he stipulates that God only wills things in accordance with his dignity. Lying does not correspond to his dignity. God is not a being such as to wish to tell a lie. Here Anselm comes close to God's justice as willing and acting as is fitting for him.

The second passage we find in chapter I.XIII of Cur Deus Homo. In this chapter Anselm demonstrates that it is not to be tolerated that God is not given the honour due to Him. There Anselm remarks: 'Si deo nihil maius aut melius, nihil iustius quam honorem illius servat in rerum dispositione summa iustitia, quae non est aliud quam ipse deus. ${ }^{37}$ We note that in this passage Anselm speaks about justice as preserving something and here he

31 Ibid., I.X.67.1-6.

32 Ibid., II.IV.99.1-13.

33 Enders (Wahrheit und Notwendigkeit, pp. 335-9) connects these two concepts in his interpretation of Anselm's view on justice in Cur Deus Homo. However plausible it seems, Anselm himself does not make this connection.

${ }^{34}$ Anselm, Proslogion, IX.108.11-13.

35 Anselm, Cur Deus Homo, I.X.67.4-6.

36 Anselm, De Veritate, XII.196.5-8.

37 Anselm, Cur Deus Homo, I.XIII.71.15-17. 
comes close to his definition in De Veritate, XII. Further, I suggest, Anselm purposely says: in the government of the universe God's honour is being preserved most justly. But there is one thing, outside the universe, that is higher than God's honour, namely his own 'incorruptible' being. When God's justice preserves in the universe his honour most of all, his justice preserves his own being still more, namely his honour in another sense. In Cur Deus Homo, XV Anselm distinguishes between God's honour in the universe, which we give him, and the honour of God, which he has in himself. The first can be diminished, the second cannot. The honour which God has in himself is identical with his own being. ${ }^{38}$ When Anselm speaks about honour in the universe, which God as the highest justice preserves, it follows that God's justice also preserves the honour which God has in himself. That God's being is incorruptible does not exclude that you can say that God himself preserves his own being by always willing what is fitting for him. So we can see this as a glimpse of God's justice, meaning that he preserves most of all his own being - the same being that, for Anselm, is most adequately defined as that than which nothing greater can be thought. So in chapter I.XIII he comes close to thinking of God's justice as preserving his own being, without being seen working with this definition of divine justice.

The third passage of Cur Deus Homo, where Anselm is close to thinking in terms of Proslogion, XIII or De Veritate, XII, is chapter II.IV. In this chapter he sets up the first chain of his argument of book II. In book I he argued that without satisfaction no restoration of man is possible. In book II he goes the other way round and demonstrates that it is not a possibility that man will not be restored. In chapter II.IV he shows that God has made man to be eternally happy, so that God will rejoice in his creature and his creature in him. When man falls, God may choose to let him perish or he may choose to save him. The first is no real alternative for God, according to Anselm, because it is not fitting for God to fail in what he has begun to do. Therefore God will seek a way by which full satisfaction can be given in order to restore humankind. So, at the start of his salvation God acts according to what is fitting for him. In this passage again, Anselm does not relate this to God's justice as willing or acting according to his nature, nor does he say that God would not be greater than which nothing can be thought, when he lets men perish.

So, in Cur Deus Homo we see that Anselm does not use the second sense of justice explicitly, but it is not far from his mind. It is a remarkable observation that when we look at the links to the second sense of justice and take these together, you can explain why Anselm considers God's justice to be at the

38 Ibid., I.XV.72.29-73.9. 
start of the process of salvation, because God in his justice will act according to his being and will not let mankind perish. It is not fitting and therefore not just for God to let humankind perish, since God has created humanity for such a high goal as being loved by God and loving God.

Another intriguing observation is the following: God's justice in the first sense also appears to prompt to salvation. This can be seen in the chapter in which Anselm brings all his lines of argument together, namely chapter II.XX:

Now the mercy of God which, when we were considering the justice of God and the sin of mankind, seemed to you to be dead, we have found to be so great, and so consonant with justice, that a greater and juster mercy cannot be imagined. What, indeed, can be conceived of more merciful than that God the Father should say to a sinner condemned to eternal torments and lacking any means of redeeming himself, "Take my only-begotten Son and give him on your behalf', and that the Son himself should say, 'Take me and redeem yourself'. For it is something of this sort that they say when they call us and draw us towards the Christian faith. What also could be more just than that the one to whom is given a reward greater than any debt should absolve all debt, if it is presented with the feeling that is due? ${ }^{39}$

We can understand this passage as if Anselm is saying that once justice is done, mercy can triumph. God's justice is satisfied now and therefore he can be gracious. But then it is good to see what Anselm said in the line of argument before. Justice is the cause of the acceptance of the sinner. It is not only that the debts of the sinners will be acquitted, when sinners offer the Son of God to his Father. Justice motivates the acceptance of the sinner. The tension between mercy and justice is solved by justice itself. So, to be consonant does not mean that mercy and justice are harmonised only in the end, but that they are of the same mind and work to the same end. So, thinking along Anselm's own ways, we can say that justice in both senses belongs with mercy at the source of salvation. However, as we have seen, in Cur Deus Homo Anselm does not take the step to make justice in the second sense the source of salvation too. It is difficult to see why he did not take this step. But we can argue that he did not have this in mind, because if he had, then Cur Deus Homo would have been a totally different book. If he had taken this step, the tension would not have been between mercy and justice, but between justice in the first sense and justice in the second sense. Besides, Anselm would have had another reason for saying that justice concurs with

39 Ibid., II.XX.132.2-6. Translation from Anselm, The Major Works, p. 354. 
justice (namely, that it was not just to let man perish), instead of what he actually says (that it is just that Christ is rewarded for giving his life by giving salvation to the believers).

Anselm does not make up his mind about justice as clearly as we would like. The threads in his thought seem not yet knitted together to the highest possible degree of clarity. The reason why this is so, we have to guess. But we see that in Cur Deus Homo in his thinking about God's justice he was never far away from his definition of God's being as that than which nothing greater can be thought. Conceptually, it can be argued that the salvation of man is rooted in God's justice.

\section{Conclusion and evaluation of other interpretations}

Now we go back to Proslogion, IX-XI. Alongside a traditional meaning of justice, which he himself follows, we saw that Anselm tentatively contended that God is just in that he is and acts in such a manner, that he cannot be conceived to be greater. In these chapters of Proslogion he could not find an answer to the question, why it is just that God acts according to his being that than which nothing greater can be conceived. Now, in the light of De Veritate we can give an answer: justice is rectitude of will preserved for its own sake. For God rectitude of will means preserving himself. One step further would be saying that preserving himself is preserving himself as the one than which nothing greater can be conceived. But this is the missing link between his definition of justice, applied to God in De Veritate, 12 and his remarks in Proslogion, IX-XI. In Cur Deus Homo the picture does not become clearer, although we see him coming close to the meanings he gives to God's justice in Proslogion and De Veritate, as well as to the missing link. The overall impression Anselm leaves is that he himself did not have a comprehensive definition of divine justice or, at least, has not formulated a definition. So his inquiry into God's justice is partly an open-ended project.

Now I will evaluate the interpretations of Anselmian justice offered by McGrath and Corbin. First of all we can now see why such different interpretations of Anselm's view of God's justice can be given. There are many threads in his thinking that are not completely knitted to each other. Which interpretation you give depends on which thread you follow. As has become clear, I contend that it is important not to follow only one thread but to look at all the threads, and to give as comprehensive an interpretation as possible, which leaves room for the loose ends. ${ }^{40}$ McGrath's interpretation is

40 To contend that Cur Deus Homo is the last word Anselm has to say on divine justice and mercy, as Sandra Visser and Thomas Williams do, does not do justice to the complexity of Anselm's thought. Visser and Williams, Anselm (Oxford: OUP, 2009), p. 108. 
right to point out different strands about justice in Anselm's thinking, such as God's justice as his pertaining to the highest good and God's justice as implying his upholding the moral order. However, he does not do enough to try to relate the different definitions to each other, and in that way he bypasses the tensions in Anselm's thinking about justice. ${ }^{41}$ Perhaps because of his leaving aside the definition in De Veritate, McGrath does not track the meaning of divine justice as God's willing and acting as the being than which nothing greater can be thought. Corbin comes near to the kernel of Anselm's thinking about justice. Anselm works with two definitions of justice, and there is tension between them; but Corbin's interpretation of God's justice as surpassing every justice does not find ground in the text. ${ }^{42}$ Nowhere does Anselm say that God surpasses his justice. Anselm only says that God's justice is so great that it cannot be thought greater, and that it is just that he maintains himself as the being than which nothing greater can be thought. His justice means thus that he maintains himself as the one whom nothing can surpass.

41 We can say the same about McCord Adams, 'On the Goodness of God', and Plasger, Die Not-Wendigkeit der Gerechtigkeit. Moreover, McGrath reads too much into Anselm (McGrath, Iustitia Dei, pp. 76-81). He writes that Anselm works with the definition of God's justice as his action directed to the highest good. That may include the redemption of man, McGrath concludes - but Anselm does not say that anywhere. In Proslogion, IX he seems to do so, but there he says that God's justice leads to punishment as well. McGrath gives another description of justice with which Anselm works, namely, the basic God-given ordering of the universe, reflecting divine will and nature. Because of this, God cannot allow this justice to be violated and an unjust state of things to arise, since injustice in the moral order, which reflects his nature, would mean a contradiction in his nature. Therefore God has to restore the moral order. Because it is unjust for God to fail in his intentions, it is unjust to let humankind perish. Therefore God has to restore humankind, too. But in two respects McGrath reads more than Anselm writes. (1) The point for Anselm is not that injustice in the moral order would lead to a contradiction in God's nature. He only says that God ought not to tolerate something that is not to be tolerated. (2) Nowhere in Cur Deus Homo does Anselm say that God's justice implies that he has to restore humankind. McGrath seems to bring this into Cur Deus Homo from the definition of justice in the Proslogion. In Cur Deus Homo Anselm does not relate the necessity of the restoration of humankind to God's justice, but only to the fact that it is not fitting for God to let humankind perish. God will not do what is not fitting for him. You can trace this back to the justice of God as his willing and acting according to his being that than which nothing greater can be thought, but Anselm does not take that step in Cur Deus Homo.

42 The same holds true for Kienzler, Gott ist grosser, pp. 153-61, and Gäde, Eine andere Barmherzigkeit, esp. pp. 274-85. I finally mention Deme's interpretation: God's justice is that he gives each his due. When man has sinned, his due is punishment. So God has to punish. See Dániel Deme, The Christology of Anselm of Canterbury (Aldershot: Ashgate, 2003), pp. 81-2. Deme's interpretation seems not to be based the important passages we observed and so does not appear to be central in Anselm's thinking. 
So I conclude that Anselm works with two definitions of God's justice, both of which can be covered by the definition of justice as rightness of will, preserved for its own sake. The first definition is more traditional, the other one is in line with his concept of God being that than which nothing greater can be thought. This latter one is not always very explicit in Anselm's work, although it seems to be the fundamental one. The reason of the tension in Anselm's thinking in Proslogion about God's justice can be explained by referring to this second definition, because if one begins from the concept of God's goodness as goodness that cannot be thought better, then it is just that God will spare sinners. Thinking from the concept of God's justice as the justice that cannot be thought more just, it is just that he punishes sinners. We saw in Cur Deus Homo that Anselm came near the idea that divine justice is the source of salvation. It remains an open question why he does not work this out. So there is still room for seeking understanding of Anselm's concept of God's justice. 